\title{
Giant Pseudoaneurysm in Distal Anastomosis of Prosthetic Aorto-Femoral Bypass
}

\section{Róbert Novotnýa, Tomáš Maradaa, Michal Kudlaa, Květoslav Lipára Jakub Křístek $^{\mathrm{a}, \mathrm{b}}$, Jiří Novotnýc, Jiří Froněk ${ }^{\mathrm{a}, \mathrm{b}}$, Libor Janoušek ${ }^{\mathrm{a}, \mathrm{d}}$}

a Transplant Surgery Department, Institute for Clinical and Experimental Medicine, Prague

${ }^{b}$ Department of Anatomy, Second Faculty of Medicine, Charles University, Prague

' Department of Radiology, Charles University, Prague

${ }^{d}$ First Faculty of Medicine, Charles University, Prague

\section{ARTICLE INFO}

Article history:

Submitted: 27. 10. 2020

Revised: 12. 11. 2020

Accepted: 17. 11. 2020

Available online: 29. 6. 2021

Klíčová slova:

Anastomotika

Aortofemorální bypass

Pozdní komplikace

Pseudoaneurysma
SOUHRN

Úvod: Anastomotická pseudoaneurysmata (APSA) jsou pozdní komplikací cévních rekonstrukcí. Přesná prevalence APSA není známa, protože mnoho prípadů není v literatuře publikováno. Ruptura APSA je však spojena s vysokou morbiditou a mortalitou.

Metoda: Operační výkon byl proveden v celkové anestezii. Byl proveden řez v levém tř́śle současně s resekcí nekrotické kůže nad APSA. APSA bylo pečlivě vypreparováno s potvrzením nálezu CT angiografie (CTA) masivní trombotizované APSA vystupující z distální anastomózy aortofemorálního bypassu (AFB). APSA bylo plně resekováno. AFB byl částečně resekován a za pomoci protetického interpozitu prodloužen. Společná stehenní tepna byla podvázána pod tříselným vazem.

Výsledky: Pacient byl propuštěn 7. pooperační den s nízkými parametry zánětu. V současné době máme pacienta ve sledování jedenáct měsíců. Pacient má průchodnou cévní rekonstrukci bez známek anastomotického APSA na Dopplerově ultrasonografii.

Závěr: Nejčastějším místem výskytu APSA po AFB je femorální oblast. Endovaskulární léčbu Ize použít pouze ve velmi vybraných prípadech $s$ velmi vysokým rizikem komplikací souvisejících s endovaskulárními intervencemi.

(C) 2021, ČKS

\section{ABSTRACT}

Introduction: Anastomotic pseudoaneurysms (APSA) are late complications of vascular reconstructions. The precise prevalence of APSA is not known, as many cases are not published in the literature. However, the rupture of APSA is associated with high morbidity and mortality.

Method: The procedure was performed under full anesthesia. An incision was made in the left groin resecting the necrotic skin above APSA. APSA was carefully dissected, confirming the CT angiography finding of a massive thrombosed APSA arising from the distal anastomosis of the aorto-femoral bypass (AFB). The APSA was fully resected. An extension of the AFB with the use of prosthetic vascular graft was performed. The common femoral artery was ligated below the inguinal ligament. Necrotic skin from the groin was resected, and the wound was closed with a patent vascular reconstruction.

Results: The patient was discharged on the 7th postoperative day with low infection's parameters. Currently we have eleven months of follow-up on the patient. The patient has a patent vascular reconstruction without any signs of anastomotic APSA on Doppler's ultrasonography.

Conclusion: The most frequent site of APSA occurrence after AFB is the femoral region. Endovascular treatment can be used only in very selected cases with a very high risk of complications related to the endovascular devices. 


\section{Introduction}

Anastomotic pseudoaneurysms (APSA) are late complications of vascular reconstructions. The precise prevalence of APSA is not known, as many cases are not published in the literature. However, the rupture of APSA is associated with high morbidity and mortality ranging from 20 $40 \%$. $^{1}$ Skourtis et al. demonstrated in his series of 49 patients that anastomosis in the femoral region is the most frequent site for APSA formation. ${ }^{1}$ The gold standard in the treatment of APSA is open repair consisting of the entire APSA resection followed by a vascular reconstruction. Endovascular modalities have limited applications in APSA treatment. ${ }^{2}$ Nevertheless, the management of APSA especially in elderly polymorbid patients demands a multidisciplinary approach between interventional radiologists and vascular surgeons. ${ }^{3}$

\section{Case presentation}

An 86-year-old male patient was admitted into our center with a suspected massive APSA in the left groin (Fig. 1). Patients medical history revealed; left prosthetic aortofemoral reconstruction (AFB) 2003, full myocardial revascularization for ischemic heart disease and mitral valve repair in 2015, compensated arterial hypertension (WHO
II. stage), atrial fibrillation, and chronic obstructive pulmonary disease (III. stage). Patients medical therapy upon admission; aspirin, spironolactone, carvedilol, atorvastatin.

Upon admission, the patient underwent a CT angiography (CTA) revealing a massive $10 \times 9 \mathrm{~cm}$ thrombosed pseudoaneurysm in the distal anastomosis of the AFB in the left groin (Fig. 2). Patient's inflammatory parameters were low (CPR: $19.5 \mathrm{mg} / \mathrm{l}$, WBC: $\left.4.5 \times 10^{9} / \mathrm{l}\right)$. Therefore, an infection was ruled out as a cause of the APSA. A prophylactic intravenous antibiotic's treatment of Cefazolin was started in the patient as no cultures were available at the moment. The patient was scheduled for an open emergency repair of the APSA due to its size and local skin necrosis in the left groin.

The procedure was performed under full anesthesia. An incision was made in the left groin resecting the necrotic skin above APSA. APSA was carefully dissected, confirming the CTA finding of a massive thrombosed APSA arising from the distal anastomosis of the AFB. The AFB above the APSA and femoral bifurcation were carefully dissected. Under full heparinization, vascular clamps were placed on the AFB and femoral bifurcation. The APSA was fully resected. An extension of the AFB with the use of $7 \mathrm{~mm}$ Silver graft (B. Braun Melsungen AG, B. Braun Aesculap AG, Tuttlingen, Germany) prosthesis was anastomosed to the femoral bifurcation (Fig. 3A). The
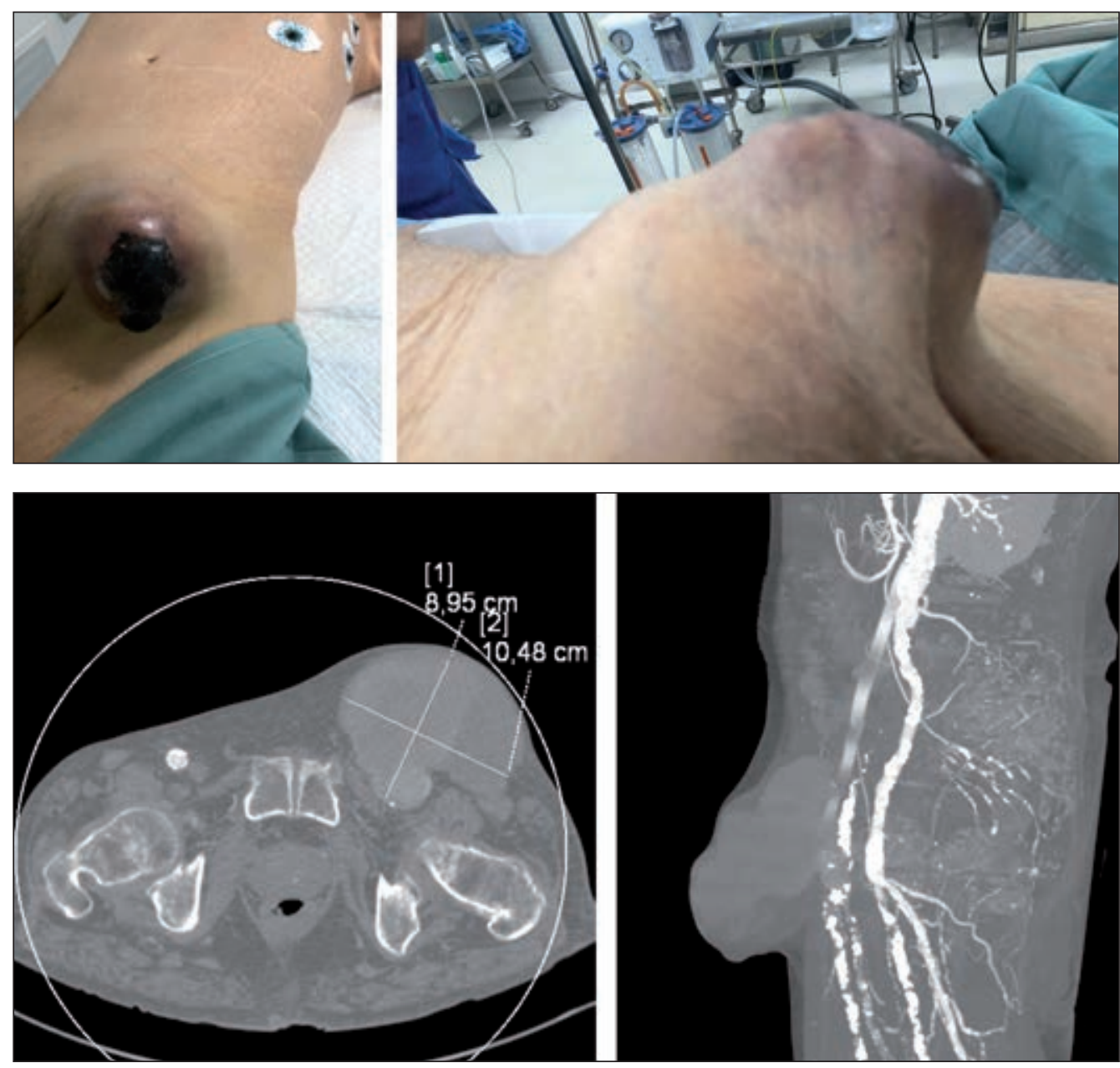

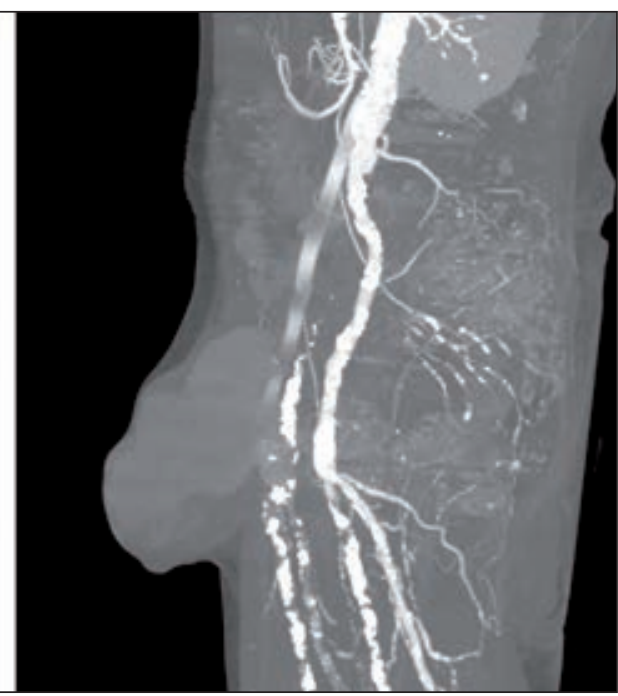

Fig. 1 - Anastomotic pseudoaneurysm after aortofemoral bypass in the left groin: local finding

Fig. 2 - CT angiography showing thrombosed $8.9 \times 10.5 \mathrm{~cm}$ anastomotic pseudoaneurysm after aorto-femoral bypass in the left groin. 

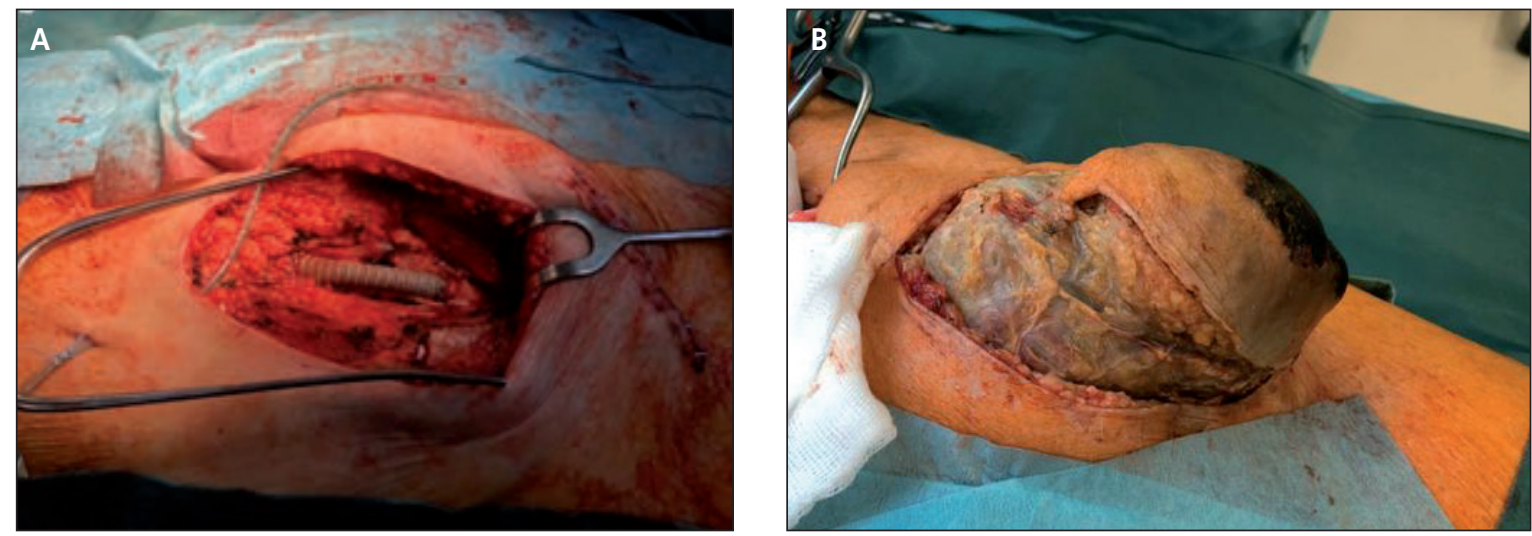

Fig. 3 - Periprocedural finding: (A) resected APSA, extension of AFB anastomosed to the femoral bifurcation using $7 \mathrm{~mm}$ Silver graft. (B) Dissected anastomotic pseudoaneurysm (APSA) after aorto-femoral bypass (AFB) in the left groin.

common femoral artery was ligated below the inguinal ligament. Cultures were taken from the wound and the AFB. Necrotic skin from the groin was resected, and the wound was closed with a patent AFB (Fig. 3B).

The postoperative course was uneventful. All cultures from the AFB and wound came negative. The prophylactic intravenous antibiotic therapy with Cefazolin was stopped on the $3^{\text {rd }}$ postoperative day. The patient was discharged on the $7^{\text {th }}$ postoperative day with low infection's parameters (CPR: $\left.17 \mathrm{mg} / \mathrm{l}, \mathrm{WBC}: 4.8 \times 10^{\%} / \mathrm{l}\right)$. Patient's medication was unchanged to the medication upon admission.

Currently we have eleven months of follow-up on the patient. The patient has a patent vascular reconstruction without any signs of anastomotic APSA on Doppler's ultrasonography.

\section{Discussion}

APSA is a pulsatile mass formed by a leakage of blood through a vascular anastomosis into the surrounding soft tissues forming a hematoma with turbulent blood flow with subsequent fibrous encapsulation. ${ }^{4}$

APSA after AFB is a severe vascular complication. The timeframe for development of APSA is reported to be between 5 and 9 years after primary operation. ${ }^{5,6}$ The APSA in the femoral region is very rare with an estimated prevalence of $0.8-2.2 \% .^{7}$ Skourtis et al. showed in his analysis that femoral anastomosis was the most frequent site of APSA formation after AFB. From all of the APSA formed after AFB, 85.7\% were present in the femoral region. The associated mortality with an open emergency repair in this series was $46.6 \%$. ${ }^{1}$

Overt time a structural degeneration of a graft in a part of higher tensile stress, distal anastomosis of an $A B F$, can increase the chance of APSA formation. ${ }^{8}$ Takami et al. demonstrated that Gelatin sealed knitted dacron grafts frequently used for aorto-femoral reconstructions have been reported to dilate over up to $10.5 \%$ within five years. ${ }^{9}$ Thus, possibly playing a role in an APSA formation.

Until recently, the open repair had been the gold standard in the treatment of APSA. Emergency intervention is crucial due to high mortality, high chance of APSA rupture especially in large APSA with weekend/necrotic skin above. Klonaris et al. reported the treatment of ruptured femoral artery APSA in six patients using emergency percutaneous covered stent deployment. ${ }^{10}$ However, the placement of stent graft in the femoral region, especially common femoral artery, is very risky as femoral artery is the most frequent access site for endovascular procedures. ${ }^{11}$ The anatomical changes in the femoral artery during movement pose a high risk of stent-graft fracture, rupture and further arterial damage. ${ }^{2,12}$

\section{Conclusion}

The presented case shows the successful treatment of a giant APSA after AFB. The most frequent site of APSA occurrence after AFB is the femoral region. Endovascular treatment can be used only in very selected cases with a very high risk of complications related to the endovascular devices. Open repair of APSA is up-to-date considered to be the gold standard.

\section{Acknowledgements}

The author would like to thank doc. MUDr. Jiří Froněk, Ph.D., FRCS, and doc. MUDr. Libor Janoušek, Ph.D., FEBS, Transplant Surgery Department, Institute for Clinical and Experimental Medicine, Prague, Czech Republic for providing their opinion on this case.

\section{Conflict of interest}

The authors declare that there is no conflict of interests regarding the publication of this article.

\section{Funding}

This research received no specific grant from any funding agency in the public, commercial, or not-for-profit sectors.

\section{Informed consent}

Written informed consent was obtained from the patient for publication of this case report and accompanying images. A copy of the written consent is available for review by the Editor-in-Chief of this journal. 


\section{References}

1. Skourtis G, Bountouris I, Papacharalambous G, et al. Anastomotic pseudoaneurysms: our experience with 49 cases. Ann Vasc Surg 2006;20:582-589.

2. Baldwin D, Mashbari H, Chow KL, Sarhan M. Ruptured Superficial Femoral Artery Anastomotic Pseudoaneurysm after 30 Years. Case Rep Vasc Med 2019;2019:1679214.

3. Wu AY, Al-Jundi W, Ziadi Z, et al. Huge anastomotic femoral pseudoaneurysm following aorto-bifemoral bypass. BMJ Case Rep 2011;2011:bcr0720103160.

4. Rivera PA, Dattilo JB. Pseudoaneurysm. [Updated 2019 Nov 14]. In: StatPearls [Internet]. Treasure Island (FL): StatPearls Publishing; 2020 Jan. Available from: https://www.ncbi.nlm.nih. gov/books/NBK542244/

5. Levi N, Schroeder TV. Anastomotic femoral aneurysms: Increase in interval between primary operation and aneurysm formation. Eur J Vasc Endovasc Surg 1996;11:207-209.

6. Marković DM, Davidović LB, Kostić DM, et al. [Anastomotic pseudoaneurysms]. Srp Arh Celok Lek 2006;134:114-121. Serbian.
7. Naouli $\mathrm{H}$, Jiber $\mathrm{H}$, Bouarhroum A. False aneurysm of perforating branch of the deep femoral artery - report of two cases. Int J Surg Case Rep 2015;14:36-39.

8. Van Damme H, Deprez M, Creemers E, Limet R. Intrinsic structural failure of polyester (Dacron) vascular grafts. A general review. Acta Chir Belg 2005;105:249-255.

9. Takami Y, Tajima K, Kato W, et al. Long-term size follow-up of knitted Dacron grafts (Gelseal ${ }^{\mathrm{TM}}$ ) used in the ascending aorta. Interact Cardiovasc Thorac Surg 2012;14:529-531.

10. Klonaris C, Katsargyris A, Vasileiou I, et al. Hybrid repair of ruptured infected anastomotic femoral pseudoaneurysms: Emergent stent-graft implantation and secondary surgical debridement. J Vasc Surg 2009;49:938-945.

11. Vatakencherry G, Molloy $C$, Sheth N, et al. Percutaneous access planning, techniques and considerations for endovascular aortic repair (EVAR). Cardiovasc Diagn Ther 2018;8(Suppl 1):S184-S190.

12. Drachman DE, Armstrong EJ. Stenting the Common Femoral Artery: Crossing the Rubicon of Endovascular Treatment? JACC Cardiovasc Interv 2017;10:1355-1356. 